UDC 340.12

DOI: https://doi.org/10.21564/2075-7190.36.123272

Satokhina Natalia Ivanivna, PhD in Law, Assistant of Philosophy Department, Yaroslav Mudryi National Law University, Kharkiv, Ukraine e-mail: nataliasatokhina@gmail.com ORCID ID: http://orcid.org/0000-0003-2480-9405

\title{
LAW AS A WAY OF MASTERING THE PAST: TRUTH, JUSTICE, RECONCILIATION
}

The present essay explains law as a way of mastering the past in case of large-scale human rights violations. On the example of the theory and practice of transitional justice, such key strategies for mastering the past as truth, justice and reconciliation are viewed as forms of mutual recognition. The very phenomenon of transitional justice is conceived as a 'border situation', which makes it possible to clarify the true nature of law as an antithesis to violence and its fundamental connection with the peace.

Keywords: mastering the past; transitional justice; truth; justice; reconciliation; recognition.

Introduction. Human beings exist in time, that's why they are continuously dealing with the past through the mechanisms of memory and forgetting. When the past is connected with injustice, the law is the very first way of dealing with it. As the australian philosopher A. Czarnota observes in this regard, 'law as a system of norms and institutions is a mechanism of systematic memory and forgetting' $[1, p$. 187]. However, the extraordinary nature of injustice paralyzes the usual mechanisms of memory and forgetting. It is the sense in which the subtle remark by M. Blanchot should be understood: 'A disaster always happens after it has happened'. A look at the world history as the history of disasters is fairly common. Suffice it to recall W. Benjamin's famous description of the Angel of history: a squally wind from heaven carries him into the future to which he turned his back, while the mountain of debris rises to the sky before him [2, p. 257-258]. The problem is that the disasters never remain buried under rubble. Massive human rights violations raise questions not only about justice, but about the dealing with the past in general, showing the limited abilities of law as the way of the interaction with time.

Thus, societies that are experiencing or have experienced large-scale human rights violations as a result of dictatorship or a military conflict find themselves between times and, probably, this state lasts as long as they correlate the 'space of experience' with the 'horizon of expectations' (in the terminology of R. Koselleck $[3$, p. 255-275]), that is, master its own past. The phenomenon called transitive 
society has provoked the appearance of the concept and practice of transitional justice. These transitional societies face not only the challenge of retributive justice, but also the need to rehabilitate the victims and, above all, the challenge of a new normative values formation. In this sense, we should agree with the thesis that not only criminal law and procedure have the limited opportunities, but also the law in general. The transitive justice with its institutional innovations tries to overcome the limitations of law, linking the mastering of the past equally with the proclamation of the truth, the establishing of justice and the reconciliation [4].

The analysis of basic publications shows that the transitional justice is becoming more and more popular field of interdisciplinary studies from politics and international law to psychology and philosophy of history. The only serious study of transitional justice in Ukraine reveals the predominantly legal aspects of that phenomenon [5]. The present essay aims to represent the approach of the philosophy of law, i.e. it is structured around issue of nature of law. Recently, the transitional justice has become the subject of philosophical and legal reflection of, in particular, C. Corradetti, N. Eisikovits, D. Jacobs, C. Lawther, L. Moffett, P. Hayner, who mainly view this phenomenon primarily as a special case of justice as such, an exception that forces us to turn to an expanded concept of justice and law $[6 ; 7 ; 8 ; 9]$. Contrary to this, this paper purposes to conceive the transitional justice as a 'border situation', which makes it possible to clarify the true nature of law.

Main matter. The transition to democracy and peace is accompanied by the conflict between equally powerful moral intuitions, which appear in the key dilemmas of transitive justicee - 'truth vs. justice', 'justice vs. reconciliation', and 'truth vs. reconciliation'. For instance, South African Truth and Reconciliation Commission was forced to compromise 'amnesty for truth', and Spain transformed to democracy through the 'pact of forgetting'. However, these dilemmas are inherent legal reality as such. But if in a stable democracy they can be minimized by using legal institutions and traditions that define the priority of this or that interpretation, in the transitional period the institutions, traditions and interpretative principles themselves are in the process of formation [7]. Thus, the experience of transitive societies and the practice of transitional justice are rather appropriate optics, which allows you to see the underlying contradictions of law as such.

Before any painstaking attempts to understand the interdependence of the truth, justice and reconciliation, even intuitively, they are perceived as the same way of interaction with the world - one that can be designated as 'recognition'. French philosopher P. Ricoeur's reflections on fundamental philosophical theory of recognition in his latest book are very interesting and fruitful in this sense. Trying to follow the evolution of the human ability to recognize and be recognized the philosopher considers the identification of objects in memory and judgment as the 
first form of recognition. Then he goes on with self-identification as confirmation that we are subjects of our own experience, and then - to mutual recognition and the 'state of peace'. According to the Ricoeur, finding somebody's true identity requires recognition of person's abilities by others. Thus, the way of self-recognition ends up in mutual recognition [10, p. 1-22]. Does not demand for identification and proclamation of the truth about the past require the recognition-identification? And is the establishment of justice connected with the establishment of the subject of statements, actions, narration and responsibility? Finally, is the reconciliation between people possible without mutual recognition? Is the mastering of the past possible without going through this difficult path of recognition from the beginning to the end?

The official and public proclamation of the truth should be the very first requirement of the transitional society, because that enables the realization of almost all subsequent strategies of dealing with the past can be realized. However, it is not only the question of gaining knowledge of the relevant facts regarding the violations, but even more the matter of finding appropriate ways to acknowledge them. The truth is often known, but is not officially recognized. In such cases the issue is not so much that of a lack of knowledge as of the refusal to acknowledge the known facts. For the victims this is a redoubling of the basic violence, denial of their human dignity. The trials and specially created truth commissions differ fundamentally in the nature and degree of attention to victims. Commissions collect testimonies of witnesses and victims and analyze all versions in order to clarify the nature of what happened. Commissions provide opportunity for public hearings in which victims could be heard and share the pain and suffering with the whole society. So, perhaps, truth as acknowledgment is the most important for the victims' psychological recovery through the official recognition of their suffering. However, it is also able to resist the revisionist claims and to fight impunity [9]. Finally, it is worth mentioning that the most famous truth commission - South African Truth and Reconciliation Commission (1995-2002) - worked with the motto 'Truth - the road to reconciliation' [11].

The idea of truth as acknowledgment relates to the idea of restorative justice, which is traditionally associated with transitional justice and in some sense opposed retributive (punitive) notion of justice which first of all requires prosecution and punishment. Truth commissions represent some moral compromise - sacrificing of (retributive) justice [12]. However, is the example of transitional justice extraordinary? Does it make us take a fresh look at the idea of justice itself? The essential relationship between the justice and the restoration of the state of peace is the theme of P. Ricoeur's theory of justice. According to the philosopher, the sense of justice, that is rooted in the pursuit of the good life and takes the most ascetic rational formulation in procedural formalism, reaches the particular fullness only at the stage of the application of the 
rule to a specific situation. While teleological meaning of justice is the desire for a good life, the deontological one is identified with the law, practical wisdom means that situational judgment is aimed at strengthening social peace. The verdict of the court, of course, does not guarantee reconciliation, because in order to reconcile the parties should mutually recognize each other. But the verdict can achieve the immediate objective of the court - to end the conflict, although the ultimate goal of justice still remains the promotion of social peace. Without dwelling on this 'dream of peace that is some kind of utopia', philosopher traces the fate of the final act of judgment that pays tribute to its final goal only when it is recognized not only by judges but also by the public, victims and defendants. In particular, the measures of rehabilitation allow the guilties to recover in the fullness of their legal capacity and performance of civic duties [13, p. 133-145]. And finally, how to meet the needs of victims, who often want firstly not to hear a sentence, but to talk about the events of the past, to be heard and recognized. In other words, it is about the restorative justice - the justice, designed to bring back the dignity of both victim and offender, restoring thus the public peace.

While we can and sometimes must require the truth and justice, we can only speak about the reconciliation in the mode of desirability. However, it is the 'horizon of expectations', which correlates with the 'space of experience' of injustice. And are the truth and justice possible without reconciliation, even in such modest version, as it sets out in the final report of the South African Truth and Reconciliation Commission: 'Reconciliation requires that all South Africans accept moral and political responsibility for nurturing a culture of human rights and democracy within which political and socio-economic conflicts are addressed both seriously and in a non-violent manner' [11]? After all, is not this the reconciliation with its own past, or its mastering?

Conclusion. To sum up, mastering the past through the application of transitional justice is an example that highlights some aspects of law, which are less obvious in usual conditions. It seems the example of transitional justice is not an exception, but rather an existential 'border situation' for law like death or extremely suffering for people: such situations are extraordinary, but they highlight true nature of law, deeply connected with peace.

\section{ЛIТЕРАТУРА}

1. Чарнота А. Про яскравий випадок невизначеності, або правосуддя перехідного періоду і верховенство права. Філософія права і загальна теорія права. 2013. №2. C. 185-193.

2. Benjamin W. Theses on the Philosophy of History. Illuminations. New York: Schocken Books, 1968. P. 253-264. 
3. Koselleck R. Futures Past. On the Semantics of Historical Time. New York: Columbia University Press, 2004. 317 p.

4. The rule of law and transitional justice in conflict and post-conflict societies. Report of the Secretary-General (S/2004/616). URL: http://archive.ipu.org/splz-e/unga07/law. pdf (Last accessed: 11.01.2018).

5. Базове дослідження із застосування правосуддя перехідного періоду в Україні: монографія / за заг. ред. А. П. Бущенка, М. М. Гнатовського. К.: РУМЕС, 2017. $592 \mathrm{c}$.

6. Corradetti C. Philosophical Issues in Transitional Justice Theory: A(Provisional) Balance. Politica \& Società. 2013. № 2. P. 185-220.

7. Eisikovits N. Transitional Justice. The Stanford Encyclopedia of Philosophy (Fall 2017 Edition) / Edward N. Zalta (Ed.). URL: https://plato.stanford.edu/archives/fall2017/ entries/justice-transitional/ (Last accessed: 11.01.2018).

8. Research Handbook on Transitional Justice / C. Lawther, L. Moffett, D. Jacobs (Ed.). Edward Elgar, 2017. 576 p.

9. Hayner P. B. Unspeakable Truths: Transitional Justice and the Challenges of Truth Commissions. New York, London: Routledge, 2011. 376 p.

10. Ricoeur P. The Course of Recognition. Harvard University Press, 2007. 320 p.

11. The South African Truth and Reconciliation Commission report. Vol. 5. URL: http://www.justice.gov.za/trc/report/finalreport/Volume5.pdf (Last accessed: 11.01.2018).

12. Toit A. du. The Moral Foundations of the South African TRC: Truth as Acknowledgment and Justice as Recognition. Truth v. Justice: the Morality of Truth Commissions / R. J. Rotberg and D. Thompson (Ed.). Princeton, Oxford: Princeton University Press, 2000. P. $122-140$.

13. Ricoeur P. The Just. Chicago and London: The University of Chicago Press, 2000. $192 \mathrm{p}$.

\section{REFERENCES}

1. Czarnota, A. (2013). Pro yaskravyi vypadok nevyznachenosti, abo pravosuddia perekhidnoho periodu i verkhovenstvo prava. Filosofiia prava i zahalna teoriia pravaPhilosophy of Law and Jeneral Theory of Law, 2, 185-193 [in Ukrainian].

2. Benjamin, W. (1968). Theses on the Philosophy of History. Illuminations. New York: Schocken Books, 253-264.

3. Koselleck, R. (2004). Futures Past. On the Semantics of Historical Time. New York: Columbia University Press.

4. The rule of law and transitional justice in conflict and post-conflict societies. Report of the Secretary-General (S/2004/616). URL: http://archive.ipu.org/splz-e/unga07/law. pdf.

5. Bazove doslidzhennia iz zastosuvannia pravosuddia perekhidnoho periodu v Ukraini.

A. P. Bushchenko, M. M. Hnatovskyi (Ed.) (2017). Kyiv: RUMES [in Ukrainian]. 
6. Corradetti, C. (2013). Philosophical Issues in Transitional Justice Theory: A (Provisional) Balance. Politica \& Società, 2, 185-220.

7. Eisikovits, N. (2017). Transitional Justice. The Stanford Encyclopedia of Philosophy (Fall 2017 Edition). Edward N. Zalta (ed.). URL: https://plato.stanford.edu/archives/fall2017/ entries/justice-transitional/.

8. Research Handbook on Transitional Justice. C. Lawther, L. Moffett, D. Jacobs (Ed.) (2017). Edward Elgar.

9. Hayner, P. B. (2011). Unspeakable Truths: Transitional Justice and the Challenges of Truth Commissions. New York, London: Routledge.

10. Ricoeur, P. (2007). The Course of Recognition. Harvard University Press.

11. The South African Truth and Reconciliation Commission report. Vol. 5. URL: http://www.justice.gov.za/trc/report/finalreport/Volume5.pdf.

12. Toit, A. du (2000). The Moral Foundations of the South African TRC: Truth as Acknowledgment and Justice as Recognition. Truth v. Justice: the Morality of Truth Commissions. R. J. Rotberg and D. Thompson (Ed.). Princeton, Oxford: Princeton University Press, $122-140$.

13. Ricoeur, P. (2000). The Just. Chicago and London: The University of Chicago Press.

Сатохіна Н. І., кандидат юридичних наук, асистент кафедри філософії Національного юридичного університету імені Ярослава Мудрого, Харків,

Украӥна

\section{ПРАВО ЯК СПОСІБ ОСВОСННЯ МИНУЛОГО: ПРАВДА, СПРАВЕДЛИВІСТЬ, ПРИМИРЕННЯ}

Постановка проблеми. Існуючи у часі, людина освоює минуле постійно. Коли ж останне пов'язане з несправедливістю, найпершим механізмом його опрачювання стає право. Разом з тим приклад перехідних суспіств, які стикаються з необхідністю подолання наслідків масштабних порущень прав людини, демонструє, що можливості традиційних правових механізмів у иььому сенсі є досить обмеженими. Правосуддя перехідного періоду з його інституційними новачіями прагне подолати ці обмеження, пов'язуючи перехід до демократії та миру водночас з констатацією правди, встановленням справедливості та примиренням.

Аналіз останніх досліджень та публікацій свідчить про те, щзо теорія та практика транзитивного правосуддя останнім часом стала предметом всебічного міждисциплінарного осмислення. Водночас з філософсько-правової перспективи феномен правосуддя перехідного періоду розглядається переважно як виняток, що вимагає ситуативного розширення уявлення про право і справедливість. Натомість метою цієї статті $\epsilon$ погляд на транзитивне правосуддя радше як на «граничну ситуацію», що дозволяє прояснити справжню природу права як антитези насильству та його фундаментальний зв'язок з миром. 
Виклад основного матеріалу. Перехід до демократії та стану миру супроводжується ключовими дилемами транзитивного правосуддя: «правда vs. справедливість», «справедливість vs. примирення», «правда vs. примирення». Притаманні правовій реальності як такій, у період транзиту иі дилеми загострюються, оскількі механізми їх пом'якшення, присутні у стабільній демократії, тут самі перебувають на стадї формування. Тому правосуддя перехідного періоду пов'язує перехід до демократії та миру водночас із констатаиією правди, встановленням справедливості та примиренням.

Правда, справедливість і примирення навіть інтуїтивно сприймаються як форми єдиного способу обходження зі світом, що може бути позначений терміном «визнання», який набуває різних смислових відтінків залежно від того, чи застосовують його до предметів, до себе чи до взаємного відномення між людьми. Вимога виявлення і проголошення правди про подіїминулого виявляється вимогою визнанняідентифікації, встановлення справедливості пов'язане із встановленням суб'єкта висловлювання, дії, оповіді та відповідальності (самовизнанням), а примирення - із взаємним визнанням.

Офічійне і публічне проголошення правди має бути найпершою вимогою перехідного суспільства, позаяк тільки ї̈ виконання й уможливлює реалізацію практично всіх подальших стратегій обходження з минулим. При иьому правда тут охоплює не лише знання про окремі факти, але й усвідомлення причин, наслідків та природи того, щзо відбулося. У контексті транзитивного правосуддя правда сфокусована на викритті жорстокості попереднього режиму і конфліктів, щзо відбулись. Однак ие не лише проблема отримання знання про відповідні факти порушень, але, більшою мірою, це питання знаходження прийнятних шляхів їх підтвердження. Чи не найбільше значення правда як підтвердження має для психологічного відновлення жертв, які прагнуть офіиійного визнання їхніх страждань. Разом з тим вона також здатна протистояти ревізіоністським претензіям і боротися з безкарністю.

3 ідеєю правди як підтвердження співвідноситься ідея справедливості як визнання інших людей такими самими носіями правди та гідності. Разом правда як підтвердження і справедливість як визнання утворюють фундамент ідеї відновлювальної справедливості, з якою традииійно пов'язують правосуддя перехідного періоду і яка у певному сенсі протистоїть ретрибутивному поняттю справедливості, що вимагає передусім кримінального переслідування і покарання. Відновлювальне правосуддя натомість покликане відновити гідність як жертв, так $і$ злочиниів, відновивши, таким чином, суспільний мир.

Якщо правди і справедливості ми можемо, а інколи й зобов'язані, вимагати, то про примирення можна говорити лише в модусі бажаності. Утім, саме воно виявляється тим «горизонтом очікувань», з яким співвідноситься «простір досвіду» несправедливості. Та й чи можливі правда і справедливість без примирення, бодай у такій скромній його версії, яку викладено у підсумковій доповіді Південноафриканської Комісії правди і примирення: «примирення передбачає, що усі жителі Південної Африки беруть на себе моральну і політичну відповідальність за виховання культури прав людини і демократії, в рамках якої політичні та соціально-економіч- 
ні конфлікти вирішуються у мирний спосіб»? Зрештою, хіба не йдеться тут про примирення передусім із власним минулим, або його освоєння?

Висновки. Освоєння минулого через застосування механізмів правосуддя перехідного періоду виявляється не винятком із загального правила, а «граничною ситуацією», яка дозволяє пролити світло на справжню природу права як антитези насильству і його фундаментальний зв'язок з миром.

Коротка анотація до статті. У даній статті право розуміється як спосіб освоєння минулого в разі масштабних порушень прав людини. На прикладі теорії і практики правосуддя перехідного періоду такі ключові стратегії освоєння минулого, як констатація правди, встановлення справедливості та примирення розглядаються як форми взаємного визнання. Самий феномен транзитивного правосуддя мислиться як «гранична ситуачія», що дозволяе прояснити справжню природу права як антитези насильству і його фундаментальний зв'язок з миром.

Ключові слова: освоєння минулого; правосуддя перехідного періоду; правда; справедливість; примирення; визнання.

Сатохина Н. И., кандидат юридических наук, ассистент кафедры философии Национального юридического университета имени Ярослава Мудрого, Харьков, Украина

\section{ПРАВО КАК СПОСОБ ОСВОЕНИЯ ПРОШЛОГО: ПРАВДА, СПРАВЕДЛИВОСТЬ, ПРИМИРЕНИЕ}

В данной статье право понимается как способ освоения прошлого в случае масштабных нарушений прав человека. На примере теории и практики правосудия переходного периода такие ключевые стратегии освоения прочлого как констатаиия правды, установление справедливости и примирение рассматриваются как формы взаимного признания. Сам же феномен транзитивного правосудия мыслится как «пограничная ситуация», которая позволяет прояснить подлинную природу права как антитезиса насилию и его фундаментальную связь с миром.

Ключевые слова: освоение прошлого; правосудие переходного периода; правда; справедливость; примирение; признание.

\section{$\operatorname{son}$}

